\title{
Behavioral Effects of Central Administration of The Novel CRF Antagonist Astressin in Rats
}

\author{
Mariarosa G. Spina, Ph.D., Ana M. Basso, Ph.D., Eric P. Zorrilla, Ph.D., Charles J. Heyser, Ph.D.,
} Jean Rivier, Ph.D., Wylie Vale, Ph.D., Emilio Merlo-Pich, M.D., and G.F. Koob, Ph.D.

\begin{abstract}
Astressin, a novel corticotropin releasing factor (CRF) antagonist, has been found to be particularly potent at inhibiting the hypothalamo-pituitary-adrenal axis. The aim of the present study was to determine the effects in rats of astressin in attenuating the anxiogenic-like response produced by social stress and intracerebroventricular (ICV) CRF administration on the elevated plus-maze, and ICV CRF-induced locomotor activation in the rat.

Astressin significantly reversed the anxiogenic-like response induced by both social stress and ICV rat/ humanCRF ( $r / h C R F)$ on the elevated plus-maze, but failed to block the effects of $r / h C R F$-induced locomotor activity in
\end{abstract}

a familiar environment. When these results were compared to previous studies performed with the same paradigms using other CRF antagonists, astressin showed effects similar to those of D-PheCRF $F_{(12-41)}$ on plus-maze performance. However, contrary to $\alpha$-helicalCRF $(9-41)$ and $D$-PheCRF $(12-41)$, astressin had no effect on CRF-induced locomotor activity. These results suggest that astressin may have a unique anti-CRF profile compared to previously tested antagonists.

[Neuropsychopharmacology 22:230-239, 2000]

(c) 2000 American College of Neuropsychopharmacology.

Published by Elsevier Science Inc.
KEY WORDS: Astressin; CRF-antagonists; $r / h C R F$; Social stress; Anxiety; Elevated plus-maze; Locomotor activity

Corticotropin-releasing factor (CRF) is a 41 amino acid peptide, first isolated from ovine hypothalamus and responsible for the regulation of the pro-opiomelanocortinderived peptides secreted by the pituitary gland (Vale et

From the Institute for Medical Neurobiology (MGS), Otto-vonGuericke University, Magdeburg, Germany; Departamento de Farmacologia (AMB), Facultad de Ciencias Quimicas, Universidad de Cordoba, Cordoba, Argentina; Division of Psychopharmacology (EPZ, GFK), Department of Neuropharmacology, The Scripps Research Institute, La Jolla, California, USA; Department of Psychology $(\mathrm{CJH})$, Franklin and Marshall College, Lancaster, Pennsylvania, USA; Clayton Laboratories for Peptide Biology (JR, WV), The Salk Institute, La Jolla, California, USA; Department of Pharmacology (EM-P), Glaxo-Wellcome Richerche, Verona, Italy.

Received April 9, 1999; revised July 21, 1999; accepted August 20, 1999.

Address correspondence to: Dr. George F. Koob, Department of Neuropharmacology, CVN-7, The Scripps Research Institute, 10550 North Torrey Pines Road, La Jolla, CA 92037. Fax: 858-784-7405. E-mail: gkoob@scripps.edu al. 1981). Many studies have shown that CRF also exerts a number of autonomic and behavioral responses to stress independent of the pituitary adrenal-axis (Vale et al. 1983; Dunn and Berridge 1990; Koob et al. 1993). This evidence supports the development of synthetic CRF analogs of potential psychotherapeutic relevance. A family of structurally constrained and long-acting CRF antagonists, such as $\alpha$-helicalCRF ${ }_{(9-41)}\left[\alpha-\right.$ helCRF $\left._{(9-41)}\right]$ and $\mathrm{D}^{-P h e C R F} \mathrm{~F}_{(12-41)}$, has been identified and studied (Rivier et al. 1984; Tazi et al. 1987; Baldwin et al. 1991, Rivier et al. 1993; Hernandez et al. 1993). In particular, in vivo studies of the effects of D-PheCRF $\mathrm{P}_{(12-41)}$, injected directly into the cerebral ventricle, showed a powerful and prolonged biological action compared to other CRF analogs (Curtis et al. 1994; Menzaghi et al. 1994; Takahashi et al. 1989; Rodriguez de Fonseca et al. 1996).

Recently, a new member of the CRF-modified analog of D-PheCRF ${ }_{(12-41)}$, astressin (see Table 1), has been synthesized and tested in vitro (Gulyas et al. 1995; Aubry et al. 1997) and in vivo (Gulyas et al. 1995; Baram et al. 1996; Martinez et al. 1997, 1998; Rivier et al. 1996; 
Maecker et al. 1997; Lee and Rivier 1997; Turnbull et al. 1999; Ando et al. 1998). This peptide presents an $\alpha$-helical structure common to previously synthesized analogs. However, it also includes a bridge between the 30 and 33 amino acid within the sequence, which may account for the higher affinity for CRF receptors (Gulyas et al. 1995, Miranda et al. 1997). In a pituitary cell culture assay, astressin has been found to be 100 times more potent than $\alpha$-helCRF $F_{(9-41)}$ and 32 times more potent than D-PheCRF ${ }_{(12-41)}$ in blocking CRF-induced ACTH release (Gulyas et al. 1995). Furthermore, astressin was 10 times more potent than $\alpha$-helCRF $F_{(9-41)}$ and D-PheCRF ${ }_{(12-41)}$ in vivo in blocking the ACTH secretion induced by adrenalectomy or electroshock (Gulyas et al. 1995). In the rat, pretreatment with astressin produced a marked inhibition of both CRF- and urocortin-induced increases in plasma ACTH levels (Turnbull et al. 1999).

The aim of the present study was to characterize the central effects of astressin and its ability to antagonize the behavioral response to stress and to antagonize exogenous administration of rat/human CRF ( $\mathrm{r} / \mathrm{hCRF}$ ). The properties of astressin to reverse social defeat stress and intracerebroventricular (ICV) CRF-induced anxiogenic-like responses, reflected in a decrease in exploratory behavior of the open arms of the elevated plusmaze, and to block the locomotor activity induced by ICV administration of $r / h C R F$ in a familiar environment, were tested. The dose range of astressin used was selected according to previous studies in which the CRF antagonists D-PheCRF $(12-41)$ and $\alpha$-helCRF $(9-41)$ were used in the same testing conditions (Heinrichs et al. 1992; Merlo-Pich et al. 1993; Menzaghi et al. 1994) and according to in vitro potency data (Gulyas et al. 1995).

\section{MATERIAL AND METHODS}

\section{Subjects}

Male Wistar rats (Charles River Laboratories, Kingston, $\mathrm{NY}$ ), weighing $250 \pm 20 \mathrm{~g}$ at the start of the experiments, were housed three per cage and maintained in a temperature- and light-controlled environment on a 12- hour light/dark cycle (lights on at 6:00 AM). Animals had free access to standard rat food and tap water. The rats were allowed a 1-week period of acclimation to the animal room and were handled once before surgery. A total of 307 rats were used for this study. Animals first were tested on the elevated plus-maze.

\section{Surgery}

Animals were anesthetized with halothane and placed in a Kopf stereotaxic instrument. Stainless steel guide cannulae (23 gauge, $7-\mathrm{mm}$ long) were implanted unilaterally, $1 \mathrm{~mm}$ above the lateral ventricle $(\mathrm{AP}-0.6 \mathrm{~mm}$, $\mathrm{L}+$ or $-2.0 \mathrm{~mm}$ from bregma, and DV $-3.2 \mathrm{~mm}$ from the point of entry, according to Pellegrino et al. 1979). The cannula was secured to the skull using four stainless steel screws and dental cement and closed with a removable stylet. Animals were allowed a 1-week recovery period before testing.

\section{Peptides and ICV Injections}

Astressin [cyclo(30-33) [D-Phe ${ }^{12}, \mathrm{Nle}^{21-38}, \mathrm{Glu}^{30}, \mathrm{Lys}^{33}$ ]$\left.\mathrm{hCRF}_{(12-41)}\right]$, D-PheCRF ${ }_{(12-41)}$ and $\alpha$-helCRF ${ }_{(9-41)}$ were dissolved in double-distilled water $(\mathrm{pH}$ 6.7), and $\mathrm{r} / \mathrm{hCRF}$ was dissolved in sterile saline just before the start of each experiment and kept on ice. Both peptides were provided by the Clayton Foundation Laboratories for Peptide Biology, The Salk Institute (La Jolla, CA). Rats were injected ICV by gravity using an 8.5 -mm long injector, connected to calibrated polyethylene 10 tubing. The tubing was raised above the head of the rat until 2 or $5 \mu \mathrm{l}$ of CRF or astressin, respectively, were infused and then lowered to the height of the cannula for a 30second waiting period after the end of the injection to prevent backflow leakage. The injector was removed and replaced by a stylet. After at least a one week interval from the first experiment, animals were tested for locomotor activity. The position of the ICV cannula was verified by gravity injection of blue dye at the completion of each experiment.

Table 1. Amino Acid Sequence of CRF-Derived Synthetic Peptides with Antagonistic Properties

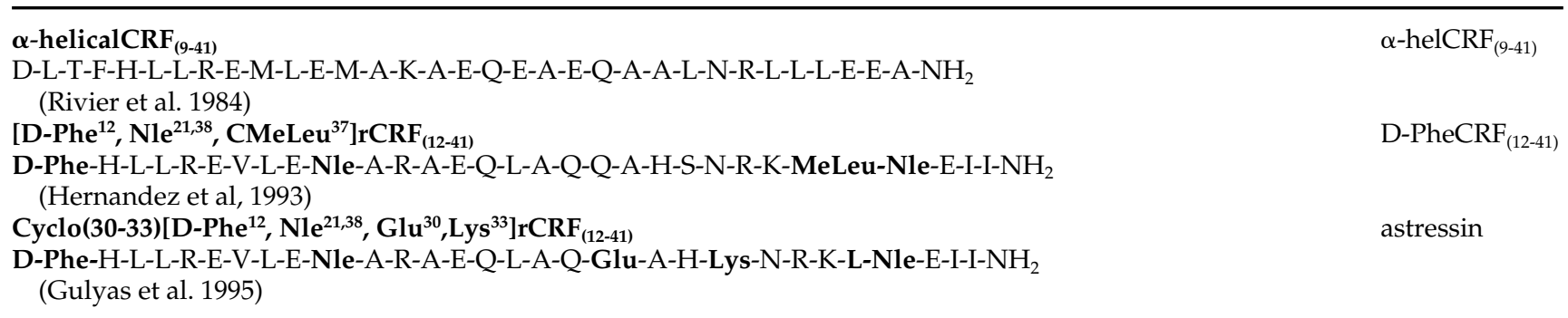

A family of structurally constrained and long-acting CRF antagonists: $\alpha$-helCRF $F_{(9-41)}, \mathrm{D}-\mathrm{PheCRF}_{(12-41)}$, and the new member of the CRF modified analog of D-PheCRF $(12-41)$, astressin. 


\section{Social Stress}

This procedure was used to stress the animals before exposure to the elevated plus-maze as previously described (Miczek 1979; Heinrichs et al. 1992; Merlo-Pich et al. 1993). Briefly, the experimental rats, "intruders," were transiently placed into the home cage of an aggressive Long-Evans male, "resident," (cage size: $72-\mathrm{cm}$ long $\times 52$-cm wide $\times 35$-cm high). Social defeat was defined as the display of a supine-submissive posture by the intruder, within 2 minutes of exposure to the resident and its attack. After the defeat, the intruder was immediately placed into a Plexiglas/wire mesh cage (20-cm long $\times 16-\mathrm{cm}$ wide $\times 32-\mathrm{cm}$ high), and the enclosure was returned inside the resident cage for 30 minutes. This procedure allowed the experimental rat to remain safe, without any physical distress, but under the continuous aggression of the resident, and it has been shown to produce a significant anxiogenic-like response (Heinrichs et al. 1992; Merlo-Pich et al. 1993).

\section{Elevated Plus-Maze}

The elevated plus-maze apparatus was made of Plexiglas and consisted of four arms $(50-\mathrm{cm}$ long $\times 10-\mathrm{cm}$ wide): two of them had dark walls $40-\mathrm{cm}$ high (enclosed arms) and the other two had only ledges $0.5-\mathrm{cm}$ high (open arms). The two open arms were provided with the same amount of light, 1.5-2.0 lux. Light intensity was kept low in order to balance the amount of time spent by each animal within the open and the closed arms. The apparatus was elevated $50 \mathrm{~cm}$ above the ground. For testing, rats were placed individually onto the center of the maze facing a closed arm and removed after a 5-min testing period. The apparatus was carefully wiped with a damp sponge and dried after each trial. Time spent on each arm and in the center, and the number of entries for each arm, were recorded automatically by photocell beams and a computer program. Data were presented as percentage of time spent in the open arms compared to the total time spent on closed and open arms. The number of entries was represented as the total number of entries in closed and open arms. All testing occurred during the dark period of the light/dark cycle, between 6:00 PM and 12:00 AM. Testing the animals during this time allows for high basal exploratory activity by which to measure stressinduced or CRF-induced suppression of exploration. Each animal was naive and was tested only once on this apparatus.

\section{Locomotor Activity}

The locomotor activity apparatus consisted of 16 wire mesh cages $(20 \times 25 \times 36 \mathrm{~cm})$ with two horizontal infrared photocell beams located across the long axis of the cage, $2 \mathrm{~cm}$ above the floor and $16 \mathrm{~cm}$ from one another. Beam interruptions were recorded by a computer and printed out every 10 minutes. Activity was recorded over 3 hours and behavior was observed every 30 minutes. White noise (70 db) was used during the habituation period and testing. All experiments were performed between 8:30 AM and 4:00 PM, which corresponded to the inactive phase of the animal's diurnal rhythm. This allows larger stimulation of locomotor activity by CRF and eliminates problems of a ceiling effect, as is observed with other stimulant treatments.

\section{EXPERIMENTAL DESIGN}

\section{Elevated Plus-Maze}

To assess the effect of astressin on spontaneous exploration of the elevated plus-maze, animals were kept in a quiet room for at least 2 hours before the beginning of the experiment. The effects of astressin on the behavioral response produced by social stress or ICV $\mathrm{r} / \mathrm{hCRF}$ administration were studied by injecting the antagonist ICV immediately after 30-minute exposure to the "resident rat" in the first experiment, or 30 minutes after ICV injection of $0.5 \mu \mathrm{g} / 2 \mu \mathrm{l}$ of $\mathrm{r} / \mathrm{hCRF}$ in the second experiment. After a single ICV injection of either vehicle (water $\mathrm{pH}$ 6.7) or a different dose of antagonist, rats were placed back in their home cage for a waiting period of 5-7 minutes before the beginning of the test and then tested on the elevated plus-maze. For these experiments, the doses of astressin injected ICV were 0.04, 0.2, and $1.0 \mu \mathrm{g} / 5 \mu \mathrm{l}$ and 1.0 and $5.0 \mu \mathrm{g} / 5 \mu \mathrm{l}$, respectively.

\section{Locomotor Activity}

To determine the effects of astressin on locomotor activity, the day before the experiment rats were habituated for 1 hour to the room and then for 5 hours to the testing cages to avoid the potential stressful nature of a novel environment. On the testing day, rats were habituated for 1 hour to the locomotor activity room and then, after 90 minutes of an adaptation period to the wire testing cages, rats' locomotor activity was measured for the 3 hours following ICV injection(s).

The effects of astressin on CRF-induced locomotor activity were studied in animals first injected with $5 \mu l$ of either vehicle (water $\mathrm{pH}$ 6.7) or one of the four doses of astressin ICV. After a period of 5-7 minutes in a holding cage, the rats received a second $2 \mu \mathrm{ICV}$ injection of either vehicle (saline) or $\mathrm{r} / \mathrm{hCRF}$. Animals then were returned to their locomotor activity cages, and their activity was monitored for the following 3 hours. For this experiment, the doses of astressin injected ICV were: 0.2 and 1.0 and $5.0 \mu \mathrm{g}$. The $\mathrm{r} / \mathrm{hCRF}$ dose used was $0.5 \mu \mathrm{g}$. Also, the effects of astressin on spontaneous 
locomotor activity were studied in animals injected ICV with $5 \mu \mathrm{l}$ of either vehicle (water $\mathrm{pH}$ 6.7) or one of the four doses of astressin. In order to replicate the effects of the CRF-antagonists $\alpha$-helCRF $(9-41)$ and D-PheCRF $(12-41)$ on spontaneous and CRF-induced locomotor activity, as an internal control, a single dose of $5 \mu \mathrm{g}$ and $1 \mu \mathrm{g} / 5 \mu \mathrm{l}$, respectively, of either one of the two antagonists was tested following the same procedure used for astressin, as described above. Both peptides were dissolved in water ( $\mathrm{pH}$ 6.7) and administered ICV.

\section{Data Analysis}

The experimental design was a between-subjects design. Parametric analysis and Dunnett's tests for a priori comparisons were used to study the effect of social stress and astressin on the elevated plus-maze and the effect of $\mathrm{r} / \mathrm{hCRF}$ and astressin administration on the elevated plus-maze and on locomotor activity (Kirk 1982). A significance level of $p<.05$ was used for all statistical analyses. Data were expressed as the mean \pm SEM.

\section{RESULTS}

\section{Effect of Astressin on the Elevated Plus-Maze Following Exposure to Social Stress or ICV Administration of $\mathrm{r} / \mathrm{hCRF}$}

Exposure to social stress significantly reduced the amount of time spent on the open arms of the elevated plus-maze in rats injected with vehicle ICV (Dunnett's test, $p<.01$, Fig. 1A). A decrease in exploration of the open arms is associated with a stress-induced anxiogenic-like effect. Administration of astressin showed a

$\mathbf{A}$

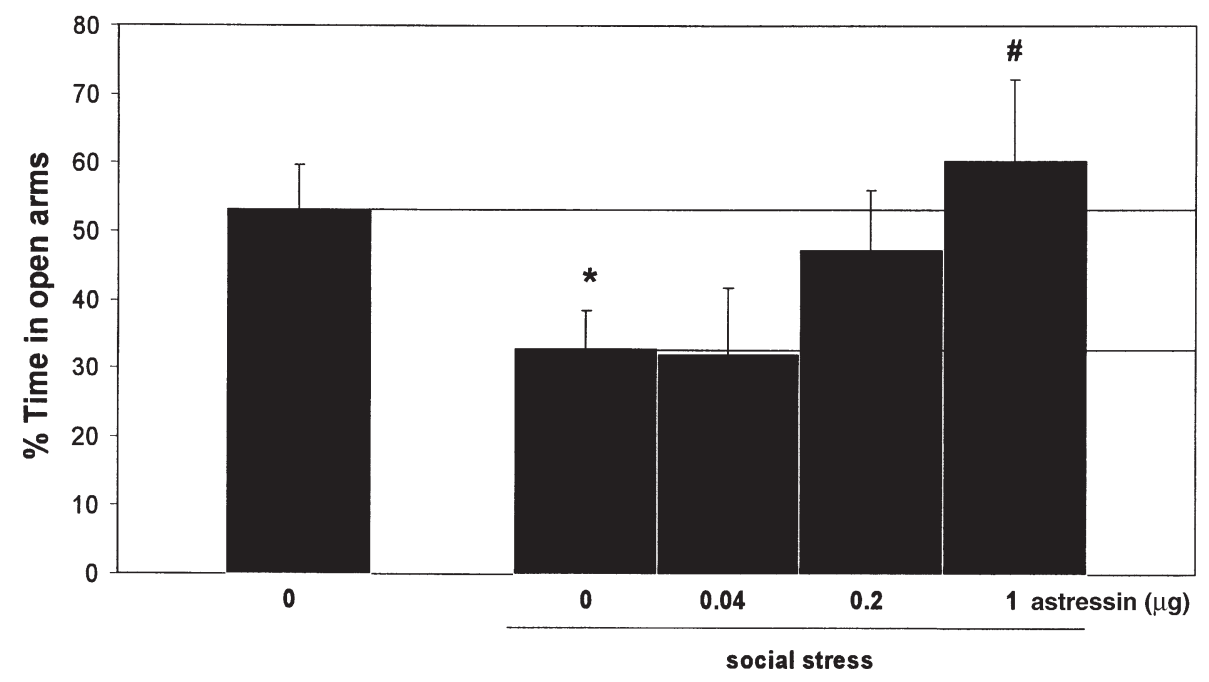

B

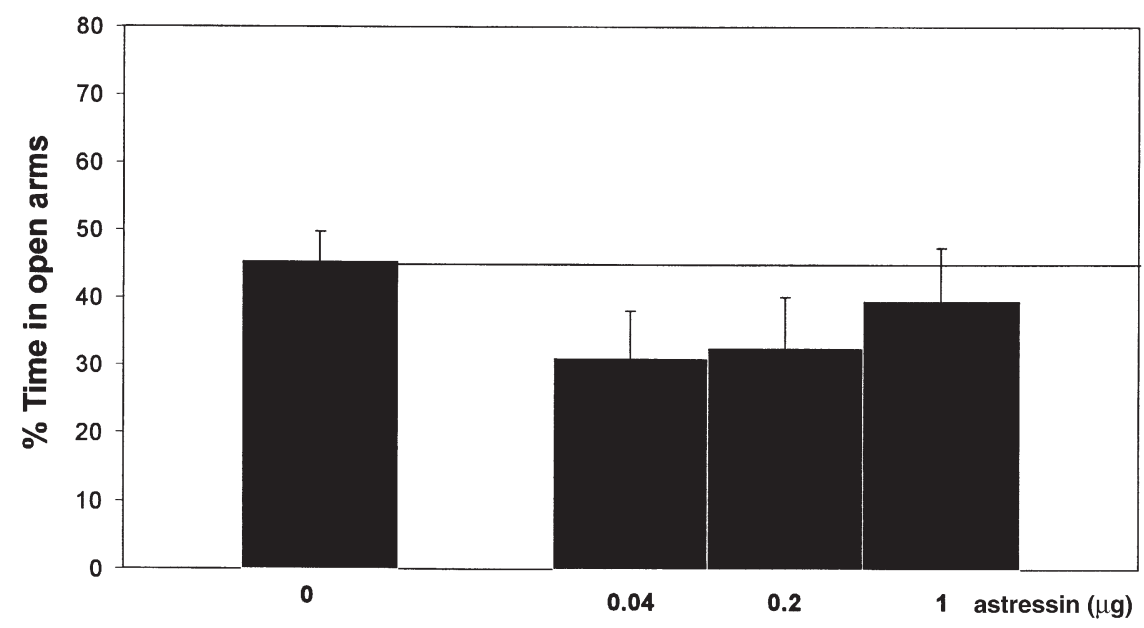

Figure 1. Effects of ICV administration of astressin on elevated plus-maze performance of rats after exposure to social stress (A) and on spontaneous elevated plus-maze performance (B); graph 1A represents the time spent on open arms (mean \pm SEM) expressed as percentage of time spent in all four arms. The number $(n)$ of animals used in each group was as follows: no social stress + vehicle $(n=9)$; social stress (ss) + vehicle $(n=6)$; ss $+0.04 \mu \mathrm{g}$ astressin $(n=8)$; ss $+0.2 \mu \mathrm{g}$ astressin $(n=5) ; \mathrm{ss}+1$ $\mu \mathrm{g}$ astressin $(n=6) .{ }^{*} p<.01$, Dunnett's test, compared to the nonstressed/control group; " $p<$ .05, Dunnett's test, compared to the stressed group administered with saline (astressin dose 0 ). The total number of arm entries per session was not different among groups (data not shown). Graph $1 \mathrm{~B}$ shows the effects produced by astressin when injected in rats not exposed to social stress. The number $(n)$ of animals used in each group was as follows: vehicle $(n=14) ; 0.04 \mu \mathrm{g}$ astressin $(n=$ $14) ; 0.2 \mu \mathrm{g}$ astressin $(n=8) ; 1 \mu \mathrm{g}$ astressin $(n=5)$. Total number of arm entries per session was not different among groups (data not shown). 
tendency to attenuate the stress effects at the doses of $0.04 \mu \mathrm{g}$ and $0.2 \mu \mathrm{g}$, with significant antagonism at the dose of $1.0 \mu \mathrm{g}$ (Dunnett's test, $p<.05$; Fig. 1A). The total number of arm entries was not affected by astressin at any dose used (data not shown), supporting the specificity of $1.0 \mu \mathrm{g}$ of astressin on open-arm exploratory activity.

In rats not exposed to social stress, low doses of astressin (0.04-0.10 $\mu \mathrm{g})$ produced a modest, nonsignificant trend toward reduction of the time spent in the open arms of the elevated plus-maze (Fig. 1B). There was no change in total number of arm entries at any of the doses tested (data not shown).

Injections of $0.5 \mu \mathrm{g} r / h C R F$ ICV significantly reduced the exploration of the open arms compared to vehicle-treated animals (Dunnett's test, $p<.05$; Fig. 2). Administration of ICV astressin reversed this anxiogenic-like effect at the dose of $5.0 \mu \mathrm{g}$ (Dunnett's test, $p<$ .05 ; Fig. 2). The total number of arm entries was not affected by astressin at any of the doses tested (data not shown). In rats pretreated with saline instead of $r / h C R F$, injections of 1.0 and $5.0 \mu \mathrm{g}$ of astressin did not produce any change in the spontaneous exploratory behavior of the animal compared to control values (Fig. 2). As in the previous experiments, the total number of arm entries was not affected by astressin at any dose used (data not shown).

\section{Effects of Astressin, $\alpha$-helCRF ${ }_{(9-41)}$, and D-PheCRF $(12-41)$ on Spontaneous and CRF-Induced Locomotor Activity}

Locomotor activity was significantly increased after $\mathrm{r} / \mathrm{hCRF}$ administration compared to saline injections $[\mathrm{F}(4,52)=5.52, p<.01$; Fig. 3]. CRF-induced locomotor activation was not significantly affected by pretreatment of astressin ICV over the dose range of $0.2-5.0 \mu \mathrm{g}$ (Fig. 3). (The same experiment was repeated four times with similar results, and only the results from the last experiment are shown.) Administration of astressin alone did not produce any effect on locomotor activity over the same dose range (Fig. 4).

As shown in Fig. 5, the enhancing effects of $r$ /hCRF administration on locomotor activity were significantly different from saline effects $[\mathrm{F}(1,68)=44.89, p<.01]$. As previously described by Menzaghi et al. (1994), both CRF-antagonists, $\alpha$-helCRF ${ }_{(9-41)}$ and D-PheCRF ${ }_{(12-41)}$ significantly attenuated CRF-induced locomotor activity at the effective dose of 5.0 and $1.0 \mu \mathrm{g}$, respectively (Dun-

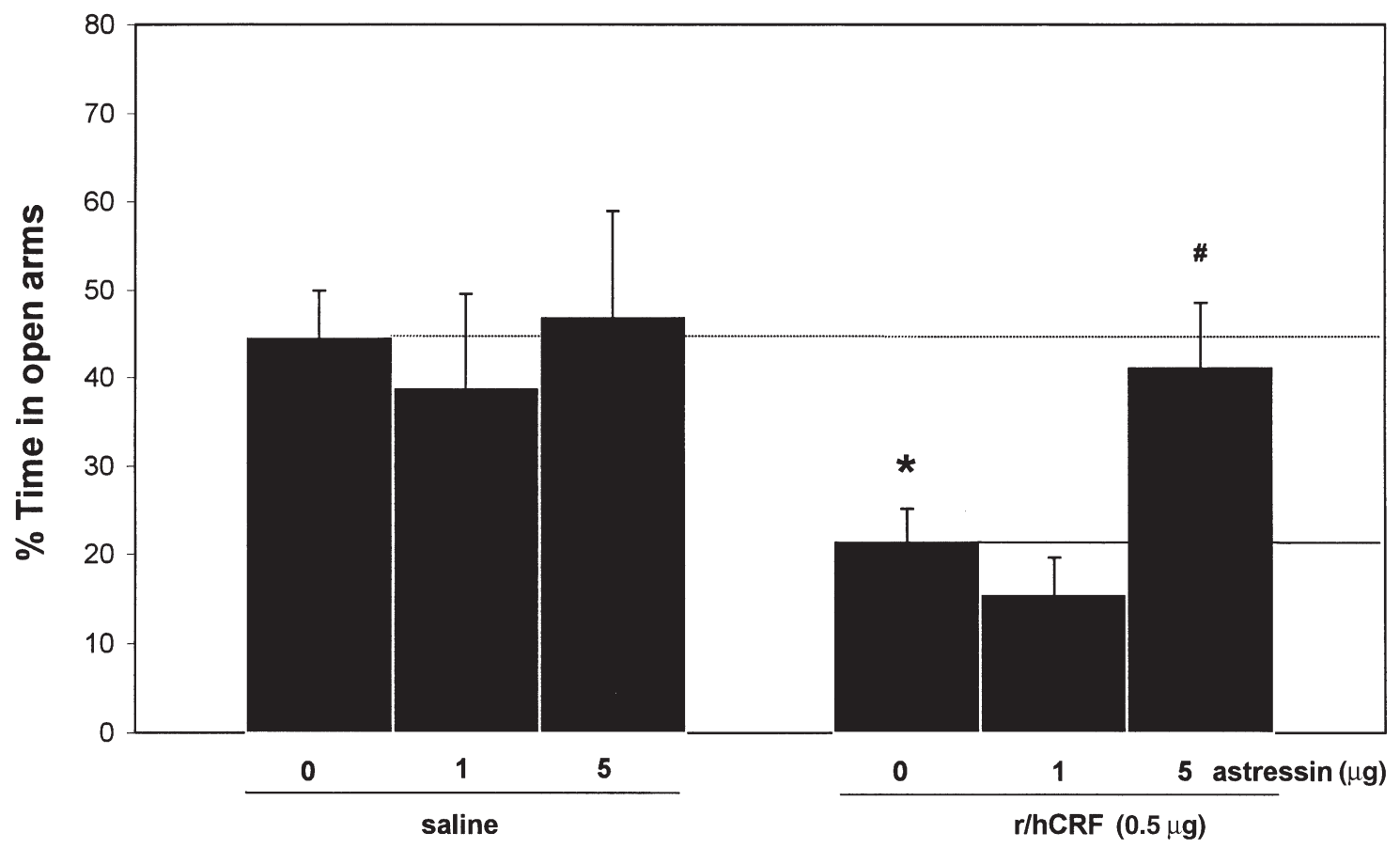

Figure 2. Effects of ICV administration of various doses of astressin versus $\mathrm{r} / \mathrm{hCRF}$-induced (0.5 $\mu \mathrm{g})$ anxiety on the elevated plus-maze performance and on the spontaneous exploration of the maze. The graph shows the time spent on open arms (mean \pm SEM) expressed as percentage of time spent in all four arms. The number $(n)$ of animals used in each group was as follows: saline + water $(n=11)$; saline $+1 \mu \mathrm{g}$ astressin $(n=7)$; saline $+5 \mu \mathrm{g}$ astressin $(n=6) ; \mathrm{r} / \mathrm{hCRF}+\mathrm{water}(n=$ $11) ; \mathrm{r} / \mathrm{hCRF}+1 \mu \mathrm{g}$ astressin $(n=13) ; \mathrm{r} / \mathrm{hCRF}+5 \mu \mathrm{g}$ astressin $(n=11) .{ }^{*} p<.01$, Dunnett's test, compared to the vehiclecontrol group. ${ }^{*} p<.01$, Dunnett's test, compared to the CRF group administered with saline (astressin dose 0). The total number of arm entries per session was not different among groups (data not shown). 
nett's test, $p<.01)$. No significant effects on spontaneous locomotor activation were produced by administration of these two peptides when given alone (Fig. 5).

\section{DISCUSSION}

In this study, central injection of $1.0 \mu \mathrm{g}$ of astressin significantly attenuated the stress-induced decrease of exploratory behavior in the elevated plus-maze in defeated rats. A higher dose of $5.0 \mu \mathrm{g}$ was necessary to antagonize the anxiogenic-like effects produced by central administration of $0.5 \mu \mathrm{g} \mathrm{r} / \mathrm{hCRF}$ on the elevated plus-maze. In contrast, both doses failed to block locomotor activation produced by central administration of the same dose of $\mathrm{r} / \mathrm{hCRF}$. These results indicate the capacity of astressin to antagonize the anxiogenic-like behavior produced by social stress as well as by the ICV infusion of $\mathrm{r} / \mathrm{hCRF}$. However, despite the high affinity of astressin for CRF receptors displayed in vitro, 32-100 times higher than the other antagonists D-PheCRF $F_{(12-41)}$ and $\alpha$-helCRF $\mathrm{F}_{(9-41)}$ (Gulyas et al. 1995), astressin showed about the same potency of D-PheCRF $\mathrm{F}_{(12-41)}$ and $\alpha$-helCRF $\mathrm{C}_{(9-41)}$ in reversing stress-induced effects on the elevated plus-maze
(Menzaghi et al. 1994). Astressin, injected in the same dose range, did not exhibit intrinsic agonist actions when tested on the plus-maze in nonstressed animals, as reported with $\alpha$-helCRF $F_{(9-41)}$ at high doses (Menzaghi et al. 1994). When astressin was injected in nonstressed rats on the elevated plus-maze, a tendency toward a reduction in the exploration of the open arms was found at low doses, suggesting a more complex effect on central CRF receptors, possibly on high affinity autoreceptors that control CRF release (Wiersma et al. 1993).

In the present study, ICV administration of astressin at any dose up to $5.0 \mu \mathrm{g}$ did not significantly reverse the stimulating effects of $\mathrm{r} / \mathrm{hCRF}$ on locomotor activity tested in a familiar environment. This result is at variance with the effects of other CRF peptides that display CRF antagonistic properties on ACTH release in vitro, such as D-PheCRF $F_{(12-41)}$ or $\alpha$-helCRF $(9-41)$. As replicated in the present study, both these antagonists significantly attenuated the CRF effects on locomotor behavior when centrally injected at doses of $1.0 \mu \mathrm{g}$ or less (Menzaghi et al. 1994). Similarly, poor effectiveness of astressin injected ICV was found in preventing CRFinduced seizures in infant rats (Baram et al. 1996). In this test, both D-PheCRF ${ }_{(12-41)}$ or $\alpha$-helCRF $F_{(9-41)}$, but not

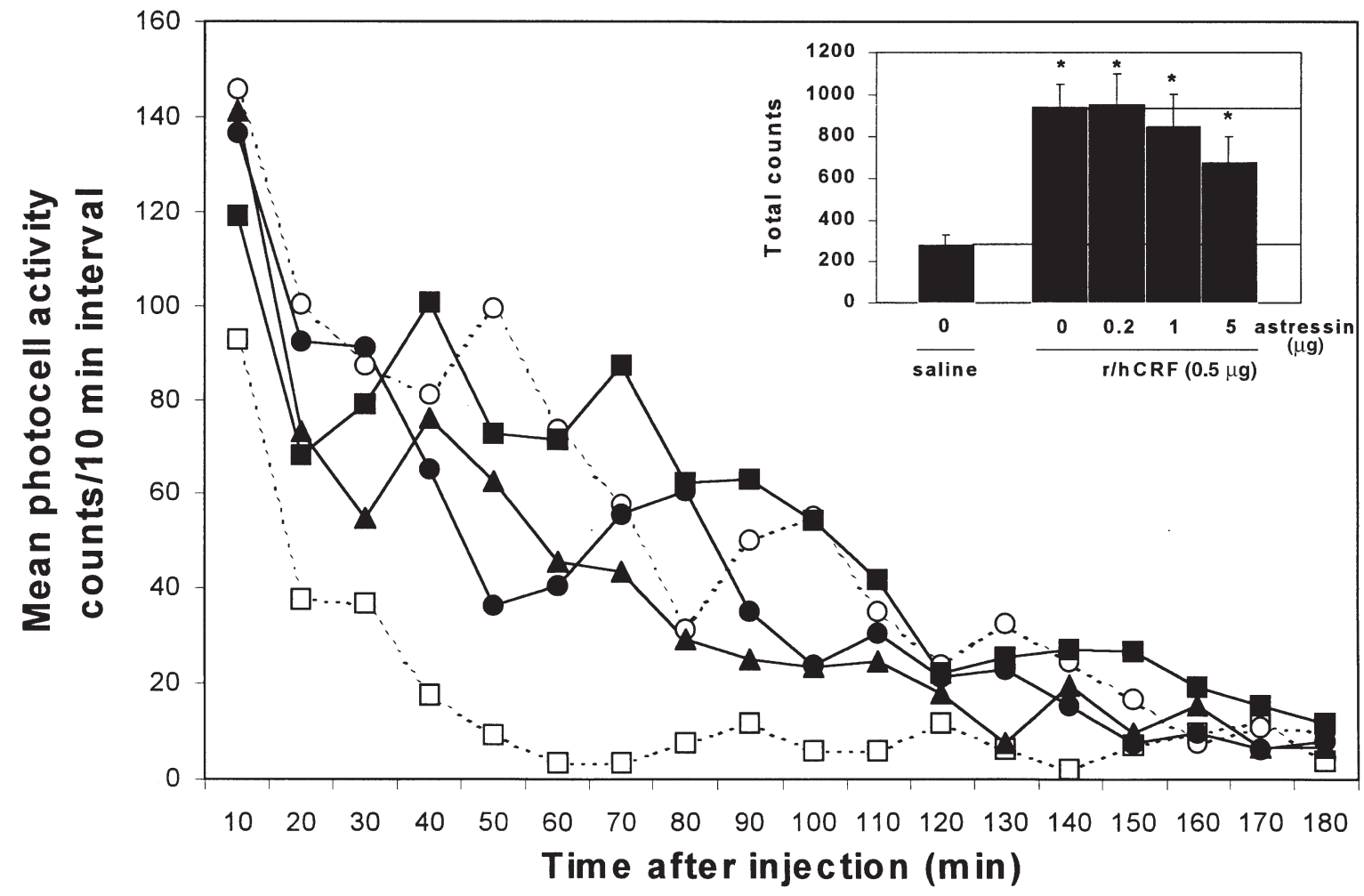

Figure 3. Effects of ICV administration of various doses of astressin on locomotor activity effects produced by ICV injection of $0.5 \mu \mathrm{g} \mathrm{r} / \mathrm{hCRF}$. Locomotor activity is expressed as mean number of beam breaks [SEM measured in 10-minute intervals (main graph) and as total counts $/ 3$ hours \pm SEM (inset)]. ${ }^{*} p<.01$, Dunnett's test, compared to control values. The number $(n)$ of animals used in each group was as follows: $\square$, water + saline $(n=12)$; $\bigcirc$, water $+\mathrm{r} / \mathrm{hCRF}(n=15)$; $\mathbf{\square}, 0.2 \mu \mathrm{g}$ astressin $+\mathrm{r} / \mathrm{hCRF}(n=9) ; \mathbf{0}, 1.0 \mu \mathrm{g}$ astressin $+\mathrm{r} / \mathrm{hCRF}(n=14)$ and $\mathbf{\Delta}, 5.0 \mu \mathrm{g}$ astressin $+\mathrm{r} / \mathrm{hCRF}(n=8)$. 


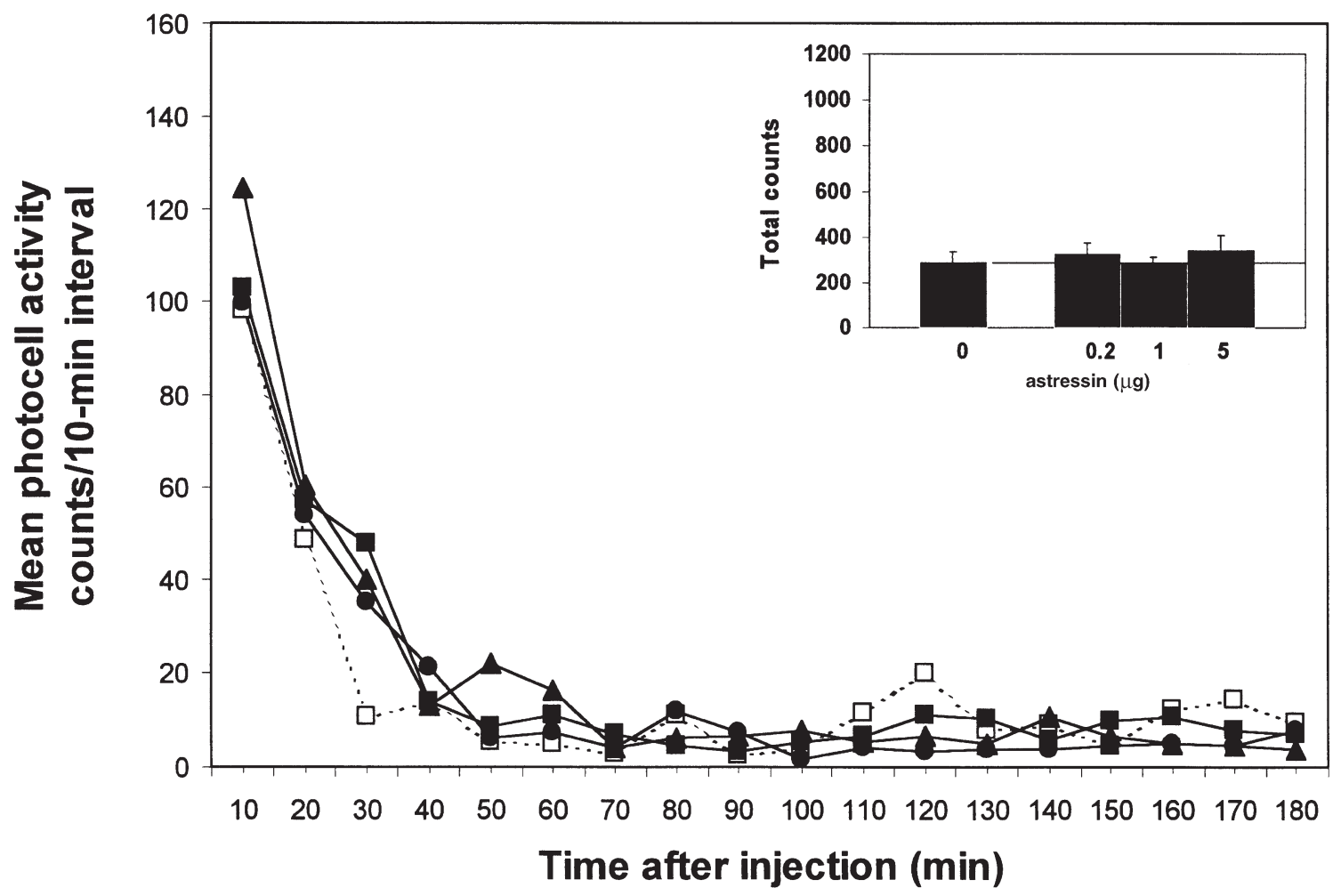

Figure 4. Effects of ICV administration of various doses of astressin on spontaneous locomotor activity. Locomotor activity is expressed as mean number of beam breaks [measured in 10-minute intervals (main graph) and as total counts $/ 3$ hours \pm SEM (inset)]. The number $(n)$ of animals used in each group is as follows: $\square$, water $(n=8) ; \mathbf{\square}, 0.2 \mu \mathrm{g}$ astressin $(n=12) ; \mathbf{0}, 1.0$ $\mu \mathrm{g}$ astressin $(n=10) ; \mathbf{\Lambda}, 5.0 \mu \mathrm{g}$ astressin $(n=12)$.

astressin, produced significant attenuation of seizure intensity. Further evidence for a poor antagonistic effect can be found in the study of Lee and Rivier (1997), in which astressin failed to block the increase in CRF mRNA expression in the parvocellular part of the paraventricular nucleus of the hypothalamus induced by alcohol treatment in the rat. However, central administration of astressin can attenuate either CRF- or urocortin-induced plasma ACTH release (Rivier et al. 1996; Turnbull et al. 1999).

Astressin also can block CRF inhibition of gastric emptying and abdominal surgery-induced gastric emptying, at doses as low as $3.0 \mu \mathrm{g}$ ICV. Doses as high as 50.0 and $20.0 \mu \mathrm{g} \alpha$-helCRF $F_{(9-41)}$ and D-PheCRF $(12-41)$, respectively, are necessary to produce the same effects (Martinez et al. 1997). Furthermore, when injected intracisternally, astressin was able to block completely CRF-, urotensin I-, and sauvagine-induced gastric emptying of a solid meal under different antagonist-to-agonist ratios (Martinez et al. 1998). Intravenous pretreatment with either D-Phe$\mathrm{CRF}_{(12-41)}(1.5 \mathrm{mg} / \mathrm{kg})$ or astressin $(0.5 \mathrm{mg} / \mathrm{kg})$ significantly attenuated the increase of plasma IL-6 produced by 1 hour of immobilization stress in rats (Ando et al. 1998). Finally, central administration of astressin at 10.0 $\mu \mathrm{g}$ was also effective in reducing water-avoidance stressinduced stimulation of fecal pellet output (Martinez et al.
1997). These results suggest that astressin can antagonize CRF and CRF-like molecule action on neural systems involved in the neuroendocrine and visceral responses to stress, but it may have less effects on those systems involved in behavioral responses to stress, and very poor effects in the locomotor activation induced by CRF.

A possible interpretation of these findings may be found in the different route of administration used in various experimental procedures, and structural interference that limits the bioavailability of the peptide at the target tissues, in particular those involved in controlling locomotor activity.

Another interpretation suggests a differential effect of astressin and other CRF antagonists on the two CRF receptors discovered until now, CRF-R, and CRF- $R_{2}$, with CRF- $\mathrm{R}_{2}$ present in the rat brain as two splice isoforms, CRF-R $R_{2 \alpha}$ and CRF- $R_{2 \beta}$ (Chen et al. 1993; Lovenberg et al. 1995; Chalmers et al. 1995; Kostich et al. 1998). In vitro experiments indicate that astressin binds with equal affinity to all receptor subtypes $\left(\mathrm{K}_{\mathrm{i}}=1.0-2.0\right.$ $\mathrm{nm}$ ); whereas, D-PheCRF ${ }_{(12-41)}$ or $\alpha$-helCRF $(9-41)$ bind preferentially to CRF-R 2 (Gulyas et al. 1995; Luthin et al. 1996; Perrin et al. 1999). When injected in vivo, astressin may produce simultaneous blockade of all CRF receptors, resulting in different effects compared to those produced by prevalent CRF- $R_{2}$ antagonists. Microinjec- 


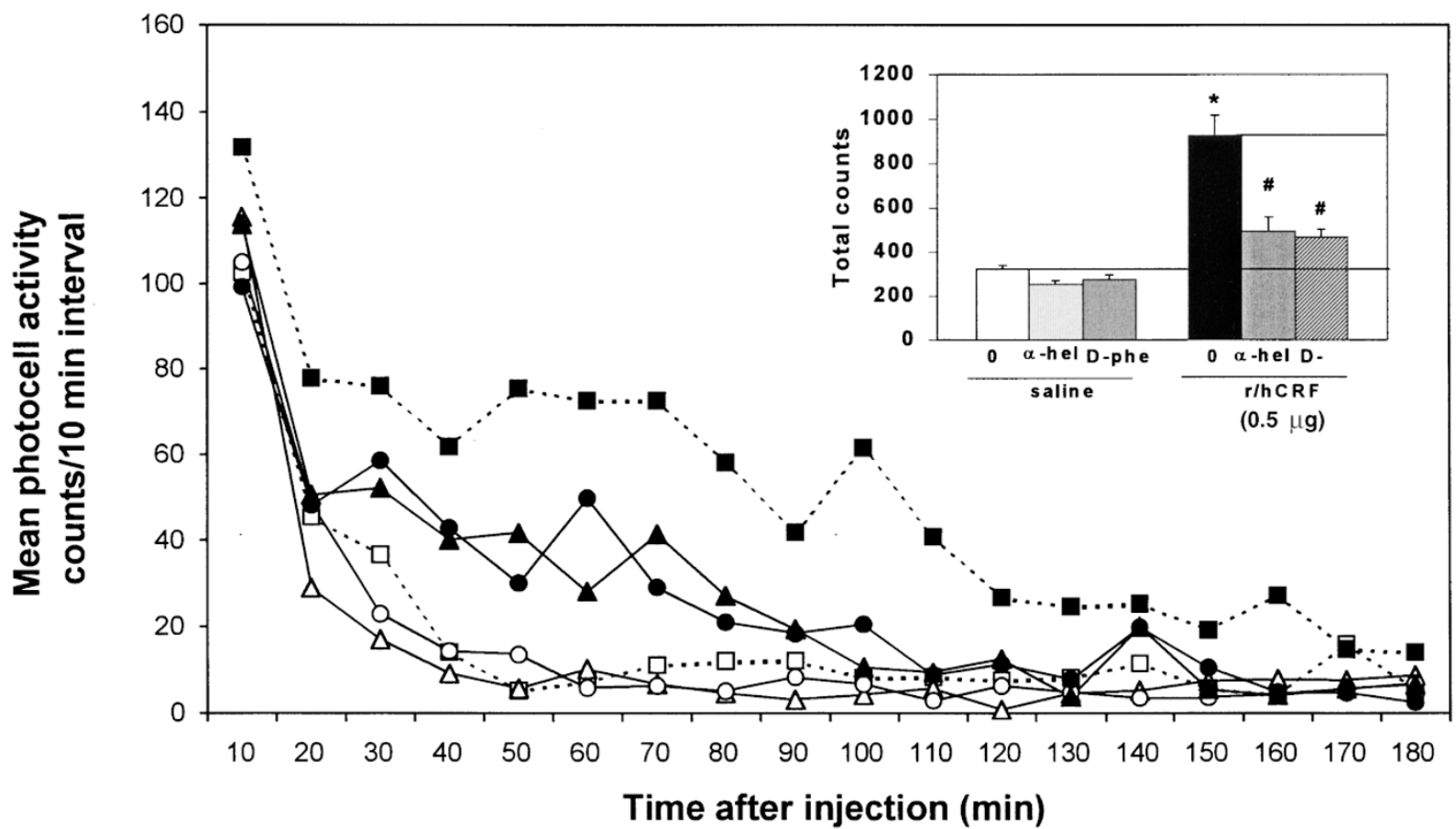

Figure 5. Effects of ICV administration of $1.0 \mu \mathrm{g}$ of D-PheCRF $(12-41)$ or $5.0 \mu \mathrm{g}$ of a-helCRF $\mathrm{F}_{(9-41)}$ on the locomotor activity

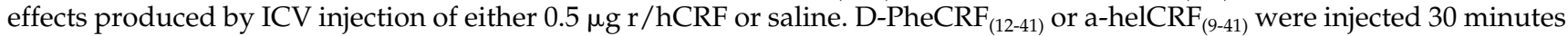
before $\mathrm{r} / \mathrm{hCRF}$. Locomotor activity is expressed as mean number of beam breaks [measured in 10-minute intervals (main graph) and as total counts $/ 3$ hours \pm SEM (inset)]. * $p<.01$, Dunnett's test, compared to control values. \#p $<.01$, Dunnett's test, compared to $\mathrm{r} / \mathrm{hCRF}$ values. The number $(n)$ of animals used in each group is as follows: $\square$, water + saline $(n=14)$; $\mathbf{\square}$, water $+\mathrm{r} / \mathrm{hCRF}(n=17) ; \triangle, 5.0 \mu \mathrm{g} \alpha$-hel + saline $(n=7) ; \bigcirc, 1.0 \mu \mathrm{g}$ D-Phe + saline $(n=12) ; \boldsymbol{\Delta}, 5.0 \mu \mathrm{g} \alpha$-hel $+\mathrm{r} / \mathrm{hCRF}(n=$ 9);, $1.0 \mu \mathrm{g}$ D-Phe $+\mathrm{r} / \mathrm{hCRF}(n=15)$.

tion of astressin into the lateral septum, a brain region enriched with CRF- $\mathrm{R}_{2}$ receptors, completely attenuates stress-induced anxiety mediated by immobilization of mice on the elevated plus-maze (Radulovic et al. 1999). This evidence indicates that septal CRF- $R_{2}$ receptors may be the common substrate for the anxiolytic effects of astressin, D-PheCRF $F_{(12-41)}$, and $\alpha$-helCRF ${ }_{(9-41)}$. However, the mechanisms underlying these differences require more studies investigating the way in which the various CRF receptors interact in determining behavioral effects. For example, CRF produces completely opposite effects on fear conditioning when microinjected into the lateral septum and into the hippocampus, brain regions enriched with CRF- $R_{2}$ and CRF- $R_{1}$, respectively (Radulovic et al. 1999).

It is unlikely that the lack of higher potency of astressin in antagonizing CRF-mediated effects could be attributable to the binding to the CRF-binding protein (CRF-BP). In fact, it has been shown that the affinity of astressin for the CRF-BP is very low and much more modest than that of $\alpha$-helCRF $(9-41)$ and D-PheCRF $(12-41)$ (Gulyas et al. 1995; Behan et al. 1995).

In conclusion, despite the remarkably higher potency shown by astressin in in vitro and in vivo studies blocking CRF-induced ACTH release, compared to other CRF-antagonists, central administration of astressin did not display the expected potency in the elevated plus-maze following social stress or central $r / h C R F$ administration. In addition, astressin failed to show any antagonistic effects of $\mathrm{r} / \mathrm{hCRF}$-induced locomotor activity. According to these results, it seems likely that the lower potency shown by astressin in vivo, compared to in vitro potency, could be attributable to the concomitance of two factors: the low bioavailability of the peptide because of structural characteristics of the compound that would limit its diffusion to certain target tissues, and the ICV administration route. Alternatively, it cannot be excluded that astressin might attenuate CRFmediated neurotransmission in those limbic structures involved in anxiogenic-like stress responses, but does not affect the CRF-dependent substrates that control locomotor behavior.

\section{ACKNOWLEDGMENTS}

The authors gratefully acknowledge Dr. Frederique Menzaghi for her great advice on the experimental procedures, Robert Lintz, Victoria Risborough, Ilham Polis, and Pete Griffin for their great help and excellent technical assistance, and Mike 
Arends for his thorough editing. This work was supported by NIH Grant DK 26741 from the National Institute of Diabetes and Digestive and Kidney Diseases. AMB was supported by Grant 1 F05 TW05262-02 from the Fogarty International Center, NIH. The experimental protocols for animals and their care were approved by the Institutional Review Committee for the use of Animal Subjects. This is publication number 11027-NP from The Scripps Research Institute.

\section{REFERENCES}

Ando T, Rivier J, Yanaihara H, Arimura A (1998): Peripheral corticotropin-releasing factor mediates the elevation of plasma IL-6 by immobilization stress in rats. Am J Physiol 275:R1461-R1467

Aubry JM, Turnbull AV, Pozzoli G, Rivier C, Vale W (1997): Endotoxin decreases corticotropin-releasing factor receptor 1 messenger ribonucleic acid levels in the rat pituitary. Endocrinology 138:1621-1626

Baldwin HA, Rassnick S, Rivier J, Koob GF, Britton KT (1991): CRF antagonist reverses the "anxiogenic" response to ethanol withdrawal in the rat. Psychopharmacology 103:227-232

Baram TZ, Koutsoukos Y, Schultz L, Rivier J (1996): The effect of "Astressin," a novel antagonist of corticotropin releasing hormone $(\mathrm{CRH})$, on $\mathrm{CRH}$-induced seizures in the infant rat: Comparison with two other antagonists. Mol Psychiat 1:223-226

Behan DP, Heinrichs SC, Troncoso JC, Liu XJ, Kawas CH, Ling N, De Souza EB (1995): Displacement of corticotropin releasing factor from its binding protein as a possible treatment for Alzheimer's disease. Nature 378:284-287

Chalmers DT, Lovenberg TW, De Souza EB (1995): Localization of novel corticotropin-releasing factor receptor (CRF2) mRNA expression to specific subcortical nuclei in rat brain: Comparison with CRF1 receptor mRNA expression. J Neurosci 15:6340-6350

Chen R, Lewis KA, Perrin MH, Vale WW (1993): Expression cloning of a human corticotropin-releasing-factor receptor. Proc Nat Acad Sci USA 90:8967-8971

Curtis AL, Grigoriadis DE, Page ME, Rivier J, Valentino RJ (1994): Pharmacological comparison of two corticotropin-releasing factor antagonists: in vivo and in vitro studies. J Pharmacol Exp Ther 268:359-365

Dunn AJ, Berridge CW (1990): Physiological and behavioral responses to corticotropin-releasing factor administration: is CRF a mediator of anxiety or stress responses? Brain Res Rev 15:71-100

Gulyas J, Rivier C, Perrin M, Koerber SC, Sutton S, Corrigan A, Lahrichi SL, Craig AG, Vale W, Rivier J (1995): Potent, structurally constrained agonists and competitive antagonists of corticotropin-releasing factor. Proc Nat Acad Sci USA 92:10575-10579

Heinrichs SC, Merlo-Pich E, Miczek KA, Britton KT, Koob GF (1992): Corticotropin-releasing factor antagonist reduces emotionality in socially defeated rats via direct neurotropic action. Brain Res 581:190-197

Hernandez JF, Kornreich W, Rivier C, Miranda A. Yamamoto G, Andrews J, Tache Y, Vale W, Rivier J (1993):
Synthesis and relative potencies of new constrained CRF antagonists. J Med Chem 36:2860-2867

Kirk RE (1982): Experimental Design Procedures for the Behavioral Sciences, 2nd ed. Pacific Grove, CA, Brooks-Cole

Koob GF, Heinrichs SC, Merlo-Pich E, Menzaghi F, Baldwin H, Miczek K, Britton KT (1993): The role of corticotropin-releasing factor in behavioral responses to stress. Ciba Found Symp 172:277-289

Kostich WA, Chen A, Sperle K, Largent BL (1998): Molecular identification and analysis of a novel human corticotropin-releasing factor (CRF) receptor: the CRF-28 receptor. Mol Endocrinol 12:1077-1085

Lee S. and Rivier C. (1997): Alcohol increases the expression of type 1, but not type 2 alpha corticotropin-releasing factor (CRF) receptor messenger ribonucleic acid in the rat hypothalamus. Mol Brain Res 52:78-89

Lovenberg TW, Chalmers DT, Liu C, De Souza EB (1995): $\mathrm{CRF}_{2 \alpha}$ and $\mathrm{CRF}_{2 \beta}$ receptor $\mathrm{mRNAs}$ are differentially distributed between the rat central nervous system and peripheral tissues. Endocrinology 136:4139-4142

Luthin DR, Youngblood KL, Rabinovich A, Brown MR, May JM (1996): Corticotropin-releasing factor (CRF) mediates ACTH release and hypotension by two pharmacologically distinct CRF receptors subtypes. Soc Neurosci Abstr 22:1545

Maecker H, Desai A, Dash R, Rivier J, Vale W, Sapolsky R (1997): Astressin, a novel and potent CRF antagonist, is neuroprotective in the hippocampus when administered after a seizure. Brain Res 744:166-170

Martinez V, Rivier J, Wang L, Tache Y (1997): Central injection of a new corticotropin-releasing factor (CRF) antagonist, astressin, blocks CRF- and stress-related alterations of gastric and colonic motor function. J Pharmacol Exp Ther 280:754-760

Martinez V, Barquist E, Rivier J, Tache Y (1998): Central CRF inhibits gastric emptying of a nutrient solid meal in rats: The role of CRF2 receptors. Am J Physiol 274:G965-G970

Menzaghi F, Howard RL, Heinrichs SC, Vale W, Rivier J, Koob GF (1994): Characterization of a novel and potent corticotropin-releasing factor antagonist in rats. J Pharmacol Exp Ther 269:564-572

Merlo Pich E, Heinrichs SC, Rivier C, Miczek KA, Fisher DA, Koob GF (1993): Blockade of pituitary-adrenal axis activation induced by peripheral immunoneutralization of corticotropin-releasing factor does not affect the behavioral response to social defeat stress in rats. Psychoneuroendocrinology 18:495-507

Miczek KA (1979): A new test for aggression in rats without aversive stimulation: Differential effects of d-amphetamine and cocaine. Psychopharmacology 60:253-259

Miranda A, Lahrichi SL, Gulyas J, Koerber SC, Craig AG, Corrigan A, Rivier C, Vale W, Rivier J (1997): Constrained corticotropin-releasing factor antagonist with i-(i+3)Glu-Lys bridges. J Med Chem 40:3651-3658

Pellegrino LJ, Pellegrino AS, Cushman AJ (1979): A Stereotaxic Atlas of the Rat Brain, 2nd ed. New York, Plenum Press

Perrin MH, Sutton S, Cervini LA, Rivier JE, Vale WW (1999): Comparison of an agonist, urocortin, and an antagonist, astressin, as radioligands for characterization of corticotropin-releasing factor receptors. J Pharmacol Exp Ther 288:729-734 
Radulovic J, Rühmann A, Liepold T, Spiess J (1999): Modulation of learning and anxiety by corticotropin-releasing factor (CRF) and stress: differential roles of CRF receptors 1 and 2. J Neurosci 19:5016-5025

Rivier C, Rivier J, Lee S (1996): Importance of pituitary and brain receptors for corticotropin-releasing factor in modulating alcohol-induced ACTH secretion in the rat. Brain Res 721:83-90

Rivier J, Rivier C, Galyean R, Miranda A, Miller C, Craig AG, Yamamoto G, Brown M, Vale W (1993): Single point D-substituted corticotropin-releasing factor analogs: Effects on potency and physicochemical characteristics. J Med Chem 36:2851-2859

Rivier J, Rivier C, Vale W (1984): Synthetic competitive antagonists of corticotropin-releasing factor: Effect on ACTH secretion in the rat. Science 224:889-891

Rodriguez de Fonseca F, Rubio P, Menzaghi F, Merlo-Pich E, Rivier J, Koob GF, Navarro M (1996): Corticotropinreleasing factor (CRF) antagonist [D-Phe12,Nle21,38,C alpha MeLeu37]CRF attenuates the acute actions of the highly potent cannabinoid receptor agonist HU-210 on defensive-withdrawal behavior in rats. J Pharmacol Exp Ther 276:56-64
Takahashi LK, Kalin NH, Vanden Burgt JA, Sherman JE (1989): Corticotropin-releasing factor modulates defensive-withdrawal and exploratory behavior in rats. Behav Neurosci 103:648-654

Tazi A, Dantzer R, Le Moal M, Rivier J, Vale W, Koob GF (1987): Corticotropin-releasing factor antagonist blocks stress-induced fighting in rats. Regul Pept 18:37-42

Turnbull AV, Vaughan J, Rivier JE, Vale WW, Rivier C (1999): Urocortin is not a significant regulator of intermittent electrofootshock-induced adrenocorticotropin secretion in the intact male rat. Endocrinology 140:71-78

Vale W, Rivier C, Brown MR, Spiess J, Koob G, Swanson L, Bilezikjian L, Bloom F, Rivier J (1983): Chemical and biological characterization of corticotropin releasing factor. Recent Prog Horm Res 39:245-270

Vale W, Spiess J, Rivier C, Rivier J (1981): Characterization of a 41-residue ovine hypothalamic peptide that stimulates secretion of corticotropin and $\beta$-endorphin. Science 213:1394-1397

Wiersma A, Bohus B, Koolhaas JM (1993): Corticotropinreleasing hormone microinfusion in the central amygdala diminishes a cardiac parasympathetic outflow under stress-free conditions. Brain Res 625:219-227 